\title{
SCHNEIDER'S SKINK (EUMECES SCHNEIDERI (DAUDIN, 1802)) AS A NEW SPECIES FOR THE FAUNA OF KAZAKHSTAN
}

\author{
Marina A. Chirikova, Yulia A. Zima, and Boris M. Gubin \\ Institute of Zoology of Ministry of Education and Science of the Republic of Kazakhstan \\ 93 Al-Farabi Prosp., Almaty 050060, Kazakhstan \\ E-mail:m.chirikova@mail.ru
}

Received 4 July 2017, accepted 22 September 2017

\begin{abstract}
In June 2017 on the territory of the Southern Kazakhstan region, on the right bank of the Syrdariya River, in the vicinities of the Darbaza mountain, under a nest of the long-legged buzzard (Buteo rufinus) the remains of 5 dead individuals of Schneider's skink (Eumeces schneideri) were found. This finding is located $110 \mathrm{~km}$ north-west from the nearest known habitation place of Schneider's skink on the Chatkal Range and allows us to include it into the herpetofauna list of Kazakhstan, and also to considerably expand our representations of its propagation north.

Key words: Eumeces schneideri, Kazakhstan.
\end{abstract}

DOI: $10.18500 / 1814-6090-2018-18-1-2-74-76$

On June 11, 2017, in the course of our herpetological expedition of studying the desert monitor (Varanus griseus), in the South-Kazakhstan Region, in the area between two cliffs of the remnant mountains on the right bank of the Syrdarya River, north of the Beltau Mountains, at 10.30 a.m., there was spotted a slender large "shining" lizard escaping into the burrow of a northern mole vole (Ellobius talpinus). At 17.00 p.m., when examining the outcrops near the Darbaza Mountain (10 km north of the Beltau Range) in the South-Kazakhstan Region $\left(41^{\circ} 50^{\prime} 15^{\prime \prime} \mathrm{N}\right.$, $68^{\circ} 32^{\prime} 19^{\prime \prime} \mathrm{E}, 400 \mathrm{~m}$ above sea level), under the longlegged buzzard's nest (Buteo rufinus) located directly on the cliff, on the day when two chicks left the nest, three dead specimens of Schneider's skink (Eumeces schneideri) were found. One specimen was well-preserved, the second one missed its tail, and only the head remained from the third one. The total body length of the first specimen was $35.7 \mathrm{~cm}$ (13.2 and $22.5 \mathrm{~cm}$ of which were the length of the body and the tail, respectively), and the second was $13.5 \mathrm{~cm}$ long (without tail). The general background of the lizard's body was olive. There were small reddish-orange spots on its back (Figure 1). Orange stripes stretched from the edge of the mouth along the sides of the body. All the specimens were included into the herpetological collection of the institute.

During the second visit to this territory on June 17,2017 , beside the same long-legged buzzard's nest, two more specimens of skink and a rangle made of skink scales were found. Within a radius of $5-7 \mathrm{~km}$ from the place where the dead specimens were found, there were no living skinks. Nevertheless, it should be noted that daytime temperature on those days reached $55^{\circ} \mathrm{C}$ which affected the activity of lizards. The explored cliffs in the area near the Darbaza Moun- tain are small hills of sedimentary origin with the highest point of $463 \mathrm{~m}$ a.s.l. with a predominantly southern orientation (Figure 2). The soil is loamy, sabulous, sometimes sandy, heavily turfed with gramineous plants. The vegetation is mainly represented by gramineous plants, gramineous-wormwood and ferulic-wormwood associations. In ravines and valleys, there is harmel (Peganum harmala) and camel thorn (Alhagi sp.). Next to the cliffs, there are several shepherds' places and cattle grazing, at some sites very intensive. Plain areas are dotted with northern mole vole burrows. Central Asian tortoise (Agryonemys horsfieldi), steppe agama (Trapelus sanguinolentus), transcaspian bent-toed gecko (Cyrtopodion (Mediodactylus) russowii), armoured glass lizard (Pseudopus apodus), race-runner (Eremias velox), desert monitor (Varanus griseus), steppe ribbon snake (Psammophis lineolatus), and spotted whip snake (Hemorrhois ravergieri) also inhabit these territories.

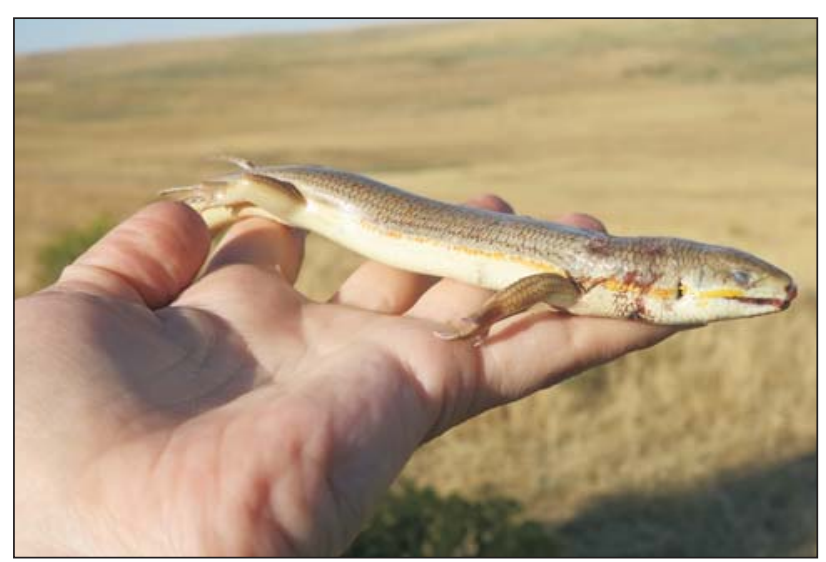

Fig. 1. Appearance of the found individuals of the Schneider's skink (photo by B. M. Gubin and M. A. Chirikova) 
It should be noted that, in addition to this pair of long-legged buzzards, there were 3 more pairs nested on the remnant mountains, at distances of 2, 4 and $6 \mathrm{~km}$ from each other, and the adults were hunting on the upper part of the plateau too. In the neighboring Kyzylkum Massif, the nests of the long-legged buzzards were located $0.9-4.7 \mathrm{~km}$ apart, on average, $3.3 \mathrm{~km}$ from each other. During their breeding season, the buzzards did not go away for more than $2-3 \mathrm{~km}$ from their nests.

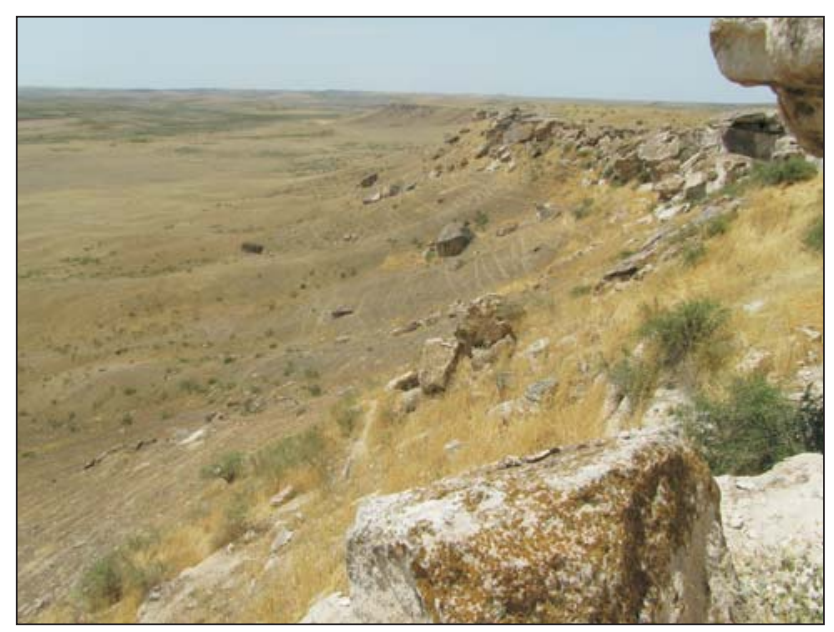

Fig. 2. Mountain Darbaza (photo by Yu. A. Zima)

The closest findings of Schneider's skink are known from Uzbekistan: from the Nuratau Range, the northern slopes of the Turkestan Range and the western foothills of the Chatkal Range (near Chinaz on the bank of the Chirchik River) (Bogdanov, 1960; Karpenko, 1970; Sindaco, Jeremčenko, 2008). It was suggested earlier that this species could inhabit the territory of Kazakhstan, the border areas near Uzbekistan - from the lower reaches of the Keles River at the eastern shore of the Shardara Reservoir to the foo- thills of the Karzhantau Range (Dujsebayeva, 2010). Our findings of skinks were made $110 \mathrm{~km}$ to the northwest of the nearest known habitat of the skink on the Chatkal Range. It is most likely that its dispersal started from here, in view of the fact that this territory is separated from the Nuratau Range (200 km away) by natural water barriers, namely, the Aydarkul Lake and the Shardara Reservoir. These findings allow us not only to include the Schneider's skink in the herpetofauna list of Kazakhstan, but also to significantly expand the information about its expansion north.

\section{Acknowledgments}

The authors would like to express their gratitude to D. Khabibullin, as well as to E. R. Baidavletov and A. A. Grachev for the organization of their trip.

The work was carried out within the framework of the grant project of the Ministry of Education and Science of the Republic of Kazakhstan (project no. 2200/GF4)

\section{REFERENCES}

Bogdanov O. P. The Fauna of the Uzbek SSR. Vol. 1. Amphibians and Reptiles. Tashkent, Izdatel'stvo AN Uzbek SSR, 1960.260 p. (in Russian).

Dujsebayeva T. N. Brief review of recent changes in the systematic list of amphibians and reptiles of Kazakhstan. In: Herpetological research in Kazakhstan and in the neighboring countries. Collection of articles dedicated to the memory of K. P. Paraskiv. Almaty, 2010, pp. 37-52 (in Russian).

Karpenko V. P. Lizards. In: Ecology of Vertebrate Animals of the Nuratau Range. Tashkent, "FAN" of the Uzbek SSR, 1970, pp. 12-40 (in Russian).

Sindaco R., Jeremčenko V. R. The Reptiles of Western Palearctic. 1. Annotated Chechlist and Distributional Atlas of the Turtles, Crocodiles, Amphisbaenians and Lizards of Europe, North Africa, Middle East and Central Asia. Latina, Edizioni Belvedere, 2008.579p.

\section{Cite this article as:}

Chirikova M. A., Zima Yu. A., Gubin B. M. Schneider's skink (Eumeces schneideri (Daudin, 1802)) as a New Species for the Fauna of Kazakhstan. Current Studies in Herpetology, 2018, vol. 18, iss. 1-2, pp. 74-76. DOI: 10.18500/1814-6090-201818-1-2-74-76. 


\title{
НОВЫЙ ДЛЯ ФАУНЫ КАЗАХСТАНА ВИД ЯЩЕРИЦЫ - ДЛИННОНОГИЙ СЦИНК (EUMECES SCHNEIDERI (DAUDIN, 1802))
}

\author{
М. А. Чирикова, Ю. А. Зима, Б. М. Губин \\ Институт зоологии МОН РК \\ Казахстан, 050060, Алматы, просп. аль-Фараби, 93 \\ E-mail:m.chirikova@mail.ru \\ Поступила в редакцию 4.07.2017 г., принята 22.09.2017 г.
}

\begin{abstract}
В июне 2017 г. на территории Южно-Казахстанской области на правобережье р. Сырдарья в окрестностях горы Дарбаза под гнездом курганника (Buteo rufinus) найдены остатки пяти мертвых особей длинноногого сцинка (Eumeces schneideri). Данная находка находится в 110 км северозападнее ближайшего известного места обитания длинноногого сцинка на Чаткальском хребте и позволяет внести его в список герпетофауны Казахстана, а также значительно расширить представление о его распространении на север.

Ключевые слова: Eumeces schneideri, Казахстан.
\end{abstract}

DOI: $10.18500 / 1814-6090-2018-18-1-2-74-76$

Благодарности. Авторы выражают искреннюю признательность Д. Хабибуллину, а также Е. Р. Байдавлетову и А. А. Грачеву за возможность осуществления поездки.

Работа выполнена при финансовой поддержке Министерство образования и науки Республики Казахстан (проект № 2200/ГФ4).

\section{Образец для цитирования:}

Chirikova M. A., Zima Yu. A., Gubin B. M. 2018. Schneider's skink (Eumeces schneideri (Daudin, 1802)) as a New Species for the Fauna of Kazakhstan // Современная герпетология. T. 18, вып. 1/2. С. 74 - 76. DOI: 10.18500/18146090-2018-18-1-2-74-76. 